This item was submitted to Loughborough's Research Repository by the author.

Items in Figshare are protected by copyright, with all rights reserved, unless otherwise indicated.

\title{
The non-adoption of supply chain management
}

PLEASE CITE THE PUBLISHED VERSION

http://dx.doi.org/10.1080/01446193.2013.830186

PUBLISHER

(c) Taylor \& Francis

VERSION

AM (Accepted Manuscript)

PUBLISHER STATEMENT

This work is made available according to the conditions of the Creative Commons Attribution-NonCommercialNoDerivatives 4.0 International (CC BY-NC-ND 4.0) licence. Full details of this licence are available at: https://creativecommons.org/licenses/by-nc-nd/4.0/

\section{LICENCE}

CC BY-NC-ND 4.0

\section{REPOSITORY RECORD}

Fernie, Scott, and Stuart Tennant. 2019. "The Non-adoption of Supply Chain Management”. figshare. https://hdl.handle.net/2134/17719. 


\title{
The non-adoption of supply chain management
}

\author{
ABSTRACT \\ Largely taken for granted within the UK construction sector has been a view that \\ supply chain management theory is robust, relevant and reliable. As such it has \\ formed a substantial aspect of previous and contemporary policy and government \\ funded research. Despite this, the prevailing view of its development and diffusion \\ over the last 15 years within the construction industry has been problematic. \\ Coincidentally, prevailing debates within the supply chain management academic \\ community point to the lack of unified theory, models of diffusion and strong \\ connections to organisation theory. Using Straussian grounded theory; iterations \\ between data and organisation theory provided a fresh perspective on the \\ development and diffusion of supply chain management in construction. This \\ inductive research provided contextually rich explanations for development and \\ diffusion that explicitly connected with and drew upon robust, relevant and reliable \\ theories of institutions, innovation diffusion, triads, quasifirms and mechanisms of \\ organizational governance. These explanations challenge the simplistic assumption \\ that chains and networks of organisations are holistically managed and controlled by \\ any single organisation or institution in the construction industry. The paper therefore \\ shifts the debate away from proselytising supply chain management towards \\ research that explores rigor, relevance and reliability of supply chain management \\ assumptions in construction. The paper also exposes the gap between industry \\ practice and policy and, questions the extent to which policy and practice do, or \\ should, constitute a recursive relationship.
}

Keywords: Supply Chain Management, Quasi-firm, Clans, Triads, Grounded Theory 


\section{Introduction}

The UK construction industry has long been perceived as characterised by a reliance on subcontracting (BERR, 2004, Hartmann and Caerteling, 2010), problematic exchange relationships (Greenwood and $\mathrm{Wu}, 2012)$ and large scale inefficiencies (Latham 1994, DETR 1998, Murray and Langford, 2003). This has presented an open door for policy makers, research funding bodies, industry change agents and academic researchers through which to promote, fund and explore change in the industry. Central to this has been an assumption in policy literature (DETR 1998, Fairclough 2002, National Platform for the Built Environment 2008, Wolstenholme 2009, IGT 2010, Cabinet Office 2011), research funding programmes, construction research literature (Briscoe and Dainty 2005, O'Brien et al., 2009, Meng et al., 2011) and professional practice literature that supply chain management is robust, relevant and reliable as an approach to deliver widespread efficiencies.

Eradicating these inefficiencies and changing practice have however not been forthcoming across organisations in the UK construction sector (Wolfenstone 2009). Indeed, this phenomenon may not be solely isolated to the construction industry (see Richey Jr et al. 2010). There is undoubtedly a disparity between stakeholders with the institutional power to promote, fund and explore change and others who possess the power to diffuse widespread and sustainable change. Despite the problematic development and diffusion of supply chain management arguably emerging as a phenomena in the literature (Tennant and Fernie 2012), it has continued to be promoted within industry policies, initiatives, research and education. The dominant assumption that supply chain management is robust, relevant and reliable as an 
approach to deliver widespread efficiencies remains largely unyielding and underexplored.

These assumptions also seems disconnected from wider concerns and debates within the supply chain management literature. This body of literature points to a widespread lack of engagement with robust organisation theory (Halldorsson et al., 2007), a rigorous orientation to theory development (De Beuckelaer \& Wagner, 2012), a paucity of middle-range theories (see Bourgeois III, 1979) as a way to connect fragmented concepts (Halldorsson et al., 2007) and an insensitivity to the context within which practice is enacted and theory developed (Fernandez-Solis, 2008). These expose a limitation of, and an inherent risk in, adopting assumptions that underpin supply chain management to shape and guide practice across multiple industry contexts. They also provide a concern that the development and diffusion of supply chain management may not be as unproblematic as assumed. Notably, whilst policy makers may easily accept and mobilise supply chain management assumptions, such uncritical acceptance is problematic for academics and practitioners engaging in the development and diffusion of supply chain management in construction.

Furthermore, despite earlier concerns of a lack of a priori theory surrounding supply chain management (Croom et al. 2000), an emphasis on barefoot empiricism (Fernie and Thorpe 2006) over theory development has continued to dominate. Drawing on the diversity of views and concerns described above, and after more than a decade of policy development, academic debate and industry engagement, there remains little clarity surrounding the development and diffusion of supply chain management in construction. Consequently, it is considered timely to explore and challenge dominant assumptions that underpin supply chain management and, to construct 
theoretical explanations that inform ongoing development and diffusion. Such scrutiny and research echoes recent calls to engage with theory development in supply chain management (Choi and Wacker, 2011, Carter, 2011) and greater theory development in the built environment itself (Koskela, 2008).

The current state of supply chain management research (general and within construction) is considered reflective of nascent theory where there exists no clearly established agreement on theory (Dehoratius and Rabinovich 2011). Nascent theory research largely engages in inductive research to help develop explanations (theory) for novel or unusual phenomena (Edmondson and McManus 2007). Within construction, research to explore development and diffusion are rare. Within the construction sector, the perceived failure to deliver efficiencies associated with developing and diffusing supply chain management in construction also presents an unusual and unexplained (or largely explored) phenomena. Nascent theory research is thus used here to broadly describe the inductive research adopted and the motivation to develop theory in this area. The grounded theory research approach adopted is consistent with nascent theory research of this type and considered to be highly appropriate (Edmondson and McManus 2007), especially as a way to develop supply chain management theory (Randall and Mello, 2012).

Grounded theory is typically used as a way to structure and provide rigor to the development of either substantive or formal theory. These theories are considered to differ with respect levels of generality (Tan 2010) or conceptual abstraction (Urquhart et al. 2010, Dey 2007). In this sense, substantive theories require comparative analysis "between or among groups within the same substantive area" (Dey 2007, p40) whereas formal theories draw from disparate groups within the same formal area. Formal theories are more abstract and general. In seeking to conduct inductive 
nascent theory research rooted within the construction sector, building theory from groups within the same substantive area has been adopted. The research strategy has thus adopted a grounded theory approach (Glaser and Strauss, 1967) as a way to develop substantive theory to explain the development and diffusion of supply chain management in the construction industry. The resultant substantive theory is codified, connected and presented as explanations for 'development and diffusion'. Their relevance to other substantive areas (such as manufacturing or retail) can in the future form the basis of attempts to develop formal theory. Ongoing theory building research within construction can also draw upon the research in this paper to reinforce and develop further substantive theory. The research here is thus argued to be only the starting point for developing theory and extending existing and novel research into the development and diffusion of supply chain management in construction

Whilst grounded theory research originated from the work of both Glaser and Strauss (1967), there are now two schools of thought (Denk et al., 2012; Carter, 2012). The Straussian approach was adopted in this paper and involved significant iteration between data and literature. Such iteration is problematic for grounded theory researchers as referees and editors typically demand an orthodox structure for academic papers (Kaufmann and Whu, 2011). In particular, the need to present literature reviews as independent from data collection and analysis. Despite this, the paper attempts to provide a linear trajectory where possible but readers are asked to be sensitive to the inability to fully avoid a storytelling style.

What follow is a broad overview of the literature on supply chain management theory and a critical analysis of the construction supply chain management literature. This is done to highlight dominant assumptions underpinning supply chain management and 
reinforce concerns regarding development and diffusion. A full description of the 'grounded theory' research strategy and process adopted is also provided to give confidence to readers concerning rigor and reliability. The subsequent findings and discussion section draws upon the iterative-inductive approach to develop interconnected explanations for the development and diffusion of supply chain management. A number of conclusions and recommendations are presented that draw upon these explanations to provide convincing arguments that support a substantive theory of non-adoption. In doing so, the contribution of the research is largely in challenging the relevance of supply chain management assumptions in the context of the UK construction sector. Additionally, theory is offered as a way to shape and influence future research aimed at policy and practice.

\section{Supply Chain Management Theory}

Contemporary views regarding supply chain management theory point at a lack of: clear definitions (Mentzer et al., 2001), relevance across contexts and difficulty in delivering generalizable findings and theoretical foundations (Ketchen and Hult, 2011). Despite this, the underlying assumption within supply chain management that every activity including transactions, processes, practices, and relationships are part of a 'chain' or 'network' remains strong. Whether internal or external, supply or demand orientated, it logically follows from this dominant assumption that chains cannot be left to serendipity; they must be actively and holistically managed (Kotzab et al., 2011). Efficiencies argued to flow from such holistic management form a significant part of arguments for industries and organisations to adopt supply chain management. It is worth noting at this point that supply chain management does not 
feature in the International Encyclopaedia of Organization Studies (Clegg and Bailey, 2008) as an approach to, or a theory of, management and organization.

In the absence of a 'unified theory' (Halldorsson et al., 2007), existing and emerging perspectives to shape this holistic management are problematic and unwieldy.

Consequently, there are no shortage of articles discussing supply chain management 'issues' (Chima, 2007; Thomas et al., 2011), 'research' (Manuj and Pholen 2012), 'practices' (Prajogo et al., 2012; Wiengarten et al., 2012) and 'knowledge' (Borgstrom 2012). However, they do not collectively or separately provide a rigorous guiding theory that retains relevance across multiple contexts. Indeed, contextually sensitive models of development and diffusion are argued to be largely absent (Kotzab et al., 2011).

What is also argued to be largely missing from supply chain management research is the mobilisation of, and connection to robust organizational theories and approaches (Halldorsson et al., 2007). Without wishing to spoil the ending of the story, the grounded theory research approach directed the research, through iterations, towards a number of robust organizational theories, approaches and their connection. These individually and collectively acted to provide contextually rich explanations for the development and diffusion of supply chain management in construction. Notable were theories of governance, transaction costs and networks, as well as an emerging theory of triads and institutions.

\section{Construction supply chain management}

Whether as a response to uncertainty or complexity (Eccles, 1981a), subcontracting within construction and the emergence of 'hollowed out' firms (Green and May, 2003), has and continues to dominate the structure of the industry. At the centre of 
concerns with subcontracting has been the issue of how subsequent networks of boundary- spanning organisations (Üsdiken et al., 1988), exchange relationships, risks and costs can be controlled. These issues are frequently wrapped up in wider long held concerns surrounding the 'fragmented' nature of the industry. They also spawn arguments that industry structure per se is problematic (Fernandez-Solis, 2008; Morledge et al. 2009) or, that it creates inefficient exchange relationships, misplaced risks and unnecessary costs. Lost amongst these arguments is a counterargument that industry structure is shaped by market demands for, and benefits from, flexibility (Dubois and Gadde, 2002; Üsdiken et al., 1988). Despite this, the pressing challenge for long established subcontracting systems and contemporary 'hollowed out' firms remains one of how to control complex networks of sub-contractors and suppliers. Supply chain management is arguably an attempt to achieve such control.

Whether current systems of control are rigorous, relevant and robust is not part of the debate surrounding the adoption of supply chain management. In doing so, debates surrounding the nature, evolution and ability to adapt and change industry structure are marginalised in favour of adopting a managerialist solution from outwith the industry. Such debates are arguably not reflective of the views of all stakeholders (Fernandez-Solis, 2008) and, it is also debatable whether it is relevant to all organisations from large repeat clients through national main contractors to small and medium sized enterprises. Fundamentally, it is unclear who in the industry is best placed to design and manage supply chains when, where and how let alone, explore "who gains and who loses, and by which mechanism of power" (Cairns, 2008).

Interpretations of supply chain management theory and practice have nonetheless reinforced and provided novel assumptions to underpin the appraisal of exchange 
relationships and transactions between clients and construction industry service and product providers (London and Kenley, 2001). However, for the construction industry to replicate the successful diffusion of supply chain management in other sectors has arguably demanded "careful translation" (Skitmore and Smyth, 2009 p. 97). The concern for many critics is that the development and diffusion of supply chain management in the construction industry runs the risk of being lost in translation. Despite this, the dominant translation emerging from the construction management literature is described as 'construction supply chain management' (see Pryke 2009) The translation over the past 15 years has seen policy makers, industry bodies, academics and professional bodies assume the need for greater industry commitment to fully integrated supply chains (Holti et al. , 2000; DETR, 1998, Wolstenholme, 2009, HM_Treasury, 2010) derived largely from the mobilisation of alternative procurement systems. The most prevalent of these systems in recent years has been the shift towards using framework agreements by public and private sector procurers. The volume of construction activity procured through these alternative systems has increased significantly (Ingirige and Sexton, 2006, RICS, 2010).

Clients mobilising these systems are typically repeat customers with a significant capital resource (Constructing_Excellence, 2005). The formation of these alliances is assumed to replace countless exchange relationships with a unitary long-standing relationship (Tommelein et al., 2009). These systems are also associated with clientled construction supply chain management and have dominated interest over the last decade (King and Pitt, 2009 Vrijhoef and Koskela 2000). Reflecting upon and reinforcing this role has consistently highlighted the prominent position construction 
clients play in shaping strategic exchange relationships with main contractors, especially public sector clients (Briscoe et al., 2004).

However, the number of construction clients with the financial and operational capacity to procure an ongoing and significant volume of projects is limited. Furthermore, contrary to assumptions of end-to-end service delivery, the development and diffusion of client-led supply chain management in construction appears to rarely extend beyond the first tier (Saad et al., 2002, Briscoe and Dainty, 2005, Skitmore and Smyth, 2009). Similarly, the contractor-led supply chain is also characteristically short and dyadic (King and Pitt, 2009). Despite this, proponents of supply chain management in construction continue to argue that supply chain management has created significantly improved opportunities for end-to-end service delivery (Rimmer, 2009).

Challenging simplistic assumptions of collaboration and trust in construction supply chain management, Cox et al (2006) further argues that the dominant pro-market transactional relationship, typical within UK construction, should be viewed as being underpinned by power and leverage (Korczynski, 1996, Beach et al., 2005). This exposes, within dominant assumptions, a tension between competition and collaboration and supports the view of win-win scenarios being largely fanciful (Cox et al., 2004). Whilst the benefits to clients of holistically managed collaborative supply chains that compete are obvious, why other organisations would (or could) acquiesce with such structures is not clear.

Indeed, providing more circumspect views of diffusing supply chain management, a number of construction management researchers point to context as pivotal to any translation of supply chain management (Green et al., 2005, Fernie and Thorpe, 
2007). Reinforcing such arguments, a repeated lack of contextual integrity is argued to misconstrue assumptions, translations and practitioners interpretations (Bresnen, 2009). Similarly, Cox et al's (2004) arguably pragmatic and critical perspective views construction supply chain management as a chronicle of convenient construction alliances beset by temporarily suppressed antagonism. Such perspectives stand in sharp contrast to those who are acquiescent regarding the simplistic assumptions, translations and utility of supply chain management to the construction sector.

There is thus sufficient disparity and concern to support a case for research that critically challenges assumptions and attempts to explain the development and diffusion of supply chain management in construction. Firstly, it cannot be assumed that there exists a unified supply chain management theory. This is problematic in providing robust, relevant and reliable support for making connections between theory and practice. Secondly, it cannot be assumed that supply chain management is underpinned by existing, robust, formal and substantive organisation theories. Thirdly, translation of supply chain management in construction has been problematic, patchy and largely unsuccessful. It cannot be assumed that development and diffusion is simplistic and straight forward let alone make sense to reflexive practitioners. Fourthly, development and diffusion has been dominated by assumptions that 'promoters' are selfless, integration and collaboration are universally relevant and good, all stakeholders benefit and that complex temporary project networks can be holistically managed as chains. Challenging these assumptions and mirroring the research approach adopted to explain 'supply chain orientation' as pivotal to change in the manufacturing industry (Omar et al., 2012), grounded theory is adopted to provide a fresh perspective that helps to explain the development and diffusion of supply chain management in construction. 


\section{Grounded theory approach}

Grounded theory is described as the discovery and development of theory systematically acquired via social inquiry 'grounded' in data collection (Goulding, 1998, Fellows and Liu, 2003). Grounded theory does have limitations (Jeon, 2004; Bryant and Charmaz, 2010). Research interest is focused on behavioural patterns (Goulding, 1998). Consequently, positivism paradigms of cause and effect do not conveniently align with the interpretative context of the research methodology (Jeon, 2004). Whilst all research is acknowledged as interpretative (Gummesson, 2003) grounded theory is "particularly suited to the study of behaviour" (Goulding, 1998. p.56) and "to understand the process by which actors construct meaning out of intersubjective experience" (Suddaby, 2006. p.634).

Critical debate has however raised some concerns regarding the legitimacy of grounded theory's epistemological standpoint rooted in interactionism and pragmatism (Corbin and Strauss, 2008). Reservations of grounded theory's epistemological integrity dwell primarily on the iterative-inductive nature of knowledge creation, reflected in the constant iteration between literature and data. For some, the iterative-inductive approach to generating so-called 'scientific' data is largely regarded as ill-considered and highly questionable (Haig, 1995). Occasionally judged by research purists as 'unscientific,' grounded theory is argued to deviate beyond acceptable boundaries of validity, reliability and objectivity (Goulding, 1998, Jeon, 2004).

Not only do grounded theorists challenge conventional wisdom regarding epistemological thinking, the methodology also questions the issue of silent authorship. The nature of grounded theory with emphasis on iterative-inductive 
research has many parallels with ethnographic study (O'Reilly, 2005) and "brings to the fore the notion of the researcher as author" (Mills et al., 2006). Consequently, a style of writing that contrasts with traditional scientific report writing are advocated (Charmaz 2006). This is described as a more literary style (Mills et al., 2006) where a "qualitative researchers needs to be something of a storyteller" (Stern, 2010 p.122). Storytelling is thus a distinctive feature of the research outcome (Holt, 2003).

Criticism of grounded theory methodology is not solely confined to supporters of positivist research methodologies. Campaigners of 'mainstream' interpretivism and qualitative data analysis (QDA) also express qualified misgivings. Within the QDA research community; 'objectivity' especially in the pursuit of research accuracy continues to be a highly regarded characteristic of the researcher. However, the 'worrisome accuracy' expressed by the QDA research community is misconstrued according to proponents of grounded theory. Glaser (2002a) clearly states that the grounded theory researcher, contrary to QDA misgivings, is not compelled to maintain objectivity or 'personal distance' in order to accurately depict social events.

There are two distinct grounded theory approaches; Glaserian (classic / traditional) and Straussian (evolved) (Jeon, 2004, Mills et al., 2006, Heath and Cowley, 2004). Comparison of the two variants of grounded theory exposes several subtle methodological differences (Mills et al., 2006). However it is the relationship between extant literature and the role of the researcher that creates most friction (Heath and Cowley, 2004). In principle, a Glaserian or classic grounded theory methodology addresses issues of data verification only subsequent to the discovery of theory. Researchers engaging with this variant of grounded theory methodology would typically commence data collection prior to any literature review. The primary objective for the Glaserian grounded theory researcher is to maintain theoretical 
sensitivity during the data collection phase. For example, initial theoretical codes emerge from the data via researchers immersing themselves in the data (Walker and Myrick 2006). Once the data collection phase is well developed extant literature can be drawn upon to substantiate emergent theory grounded in practice.

Alternatively, Staussian or evolved grounded theory methodology engages with data verification as an ongoing process (Jeon, 2004). For Strauss, "the use of self and literature are early influences" (Heath and Cowley, 2004 p.143) and as such grounded theory researchers are understood to be theoretically sensitive prior to data collection as a consequence of being "steeped in relevant literatures" (Green et al. , 2010, p119). Critics of a Straussian orientation argue that the constant iteration between data collection and extant literature coupled with subtle differences in the use of the constant comparison method and data analysis, may lead to the 'forcing of data' (Glaser, 2002a, Glaser, 2002b). On the other hand, it is questionable that researchers can ever engage in any inductive research, grounded theory or not, with an 'empty head' or tabula rasa (Andersen and Kragh, 2010). Kelle (2005 p.3) writes that "qualitative researchers who investigate a different form of social life always bring with them their own lenses and conceptual networks". A researcher's view regarding the 'forcing of data' debate will ultimately determine the grounded theory methodology adopted and the way in which the constant comparison method is deployed and data analysed.

Regardless of the criticism, grounded theory has established a positive reputation especially within social science disciplines (Mills et al., 2006). Mindful of the limitations and assumptions, the strategy chosen for this research draws upon the legitimacy of a Straussian (evolved) approach to grounded theory. In this sense, the researchers cannot claim to have initiated the study, collected and analysed data in 
the absence of early influences. Data analysis is also informed by a Straussian coding paradigm (Walker and Myrick, 2006). Despite this, the authors would claim to remain sensitive to the danger of 'forcing of data'.

Notably, the use of grounded theory as an approach to developing robust supply chain management theory features strongly within contemporary debates (Fredrik Nilsson, 2012; Gammelgaard and Flint, 2012; Manuj \& Pohlen, 2012; Denk et al., 2012; Randall and Mello, 2012). Its use as a valid research approach with the necessary rigor is thus argued to be highly relevant in developing explanations for understanding the development and diffusion of supply chain management in construction.

\section{The Research Process}

The process to ensure the validity and rigour of grounded theory research remains a contentious issue and is frequently the subject of epistemological debate and methodological tension (Astley, 1984). Given the plurality of viewpoint frequently expressed, the question of process arguably raises a central and provocative investigative dilemma. The research process adopted in this context is defined by Corbin and Strauss (2008 p.96) as:

"the ongoing action/interaction/emotion taken in response to situations, problems, often with the purpose of reaching a goal or handling a problem. The action/interaction/emotion occurs over time, involve sequences of different activities and interactions and emotional responses and have a sense of purpose and continuity". 
To assist with the validation and rigour of the research process, six recognized methodological tenets of grounded theory; namely, emergence and researcher distance, theory development, coding procedures, specific / non-optional procedures, core category and evaluation criteria (Denk et al., 2012) have been addressed. Given the contrasting interpretation between Glaser and Strauss, the six dimensions align with a Strausian or evolved understanding of grounded theory methodology.

\section{Emergence and Researcher Distance}

It is arguably the role of the researcher and their relationship with extant literature that creates most tension when reviewing a Glaser or Straussian understanding of grounded theory methodology (Heath and Cowley, 2004). Acknowledging the academic background and research experience of the authors, the notion of following a Glaser (empty head) approach to grounded theory is impractical. Consequently, prior knowledge and pre-defined perspectives contribute significantly to the formulation of the primary research question; why after more than a decade of policy development, academic debate and industry engagement, does there remains little clarity surrounding the development and diffusion of supply chain management in construction?

The collection of 'field' data commenced with 'orientation' interviews. The orientation interviews were largely informal meetings with interested stakeholders to discuss current understanding and practice of supply chain management in construction. In short, the orientation interviews addressed the knowledge gap between extant literature, prior knowledge and current industry demands and desires within the context of construction supply chain management. A central and arguably defining 
theme in the development and diffusion of supply chain management emerged from these 'orientation' meetings; namely, construction framework agreements.

\section{Theory Development}

Continuing to follow a Straussian interpretation of theory development, axial codes and sub-themes derived from the orientation meetings were catalogued and incorporated in to a semi-structured interview template. Four axial codes were identified, each with six sub-themes, see table 1.

Table 1. Semi-Structured Interview Template: Axial Codes and Sub-Themes

\begin{tabular}{|l|c|c|c|c|}
\hline Axial Codes: & $\begin{array}{c}\text { Background } \\
\text { I Context }\end{array}$ & $\begin{array}{c}\text { Supply Chain } \\
\text { Management }\end{array}$ & $\begin{array}{c}\text { Framework } \\
\text { Agreements }\end{array}$ & $\begin{array}{c}\text { Stakeholder } \\
\text { Interpretation }\end{array}$ \\
\hline $\begin{array}{l}\text { Sub- } \\
\text { Themes }\end{array}$ & Company & Understanding & Definition & Justification \\
& Competence & Implementation & Experience \\
Sarkets & Relationships & Relationships & Key Lessons \\
& Specialist & Learning & Contract \\
& Management & Audit Trail & Cost & Business Climate \\
& Innovation & KPI's & Adv. / Disadv. & Future Prospects \\
& & & & \\
\hline
\end{tabular}

The semi-structured interview procedure drew upon a 'snowballing technique' (Green et al., 2010) to identify strategic participants within the supply chain. Exploiting the social network of research informants makes this form of sampling technique susceptible to numerous biases (Van Meter, 1990) and problematic in certain circumstances. However, given the research requirement for identifying and exploring supply chains in construction, this approach underscored a major element of the theoretical sampling technique (Glaser and Holton 2004). "Theoretical sampling is concept driven" (Corbin and Strauss, 2008 p.145), an approach Hood (2007 p.157) coined as "a priori purposeful sample". This concept driven / purposeful 
sampling approach to data gathering quickly identified supply chain (concept) stakeholders. In addition, the unique attributes associated with theoretical sampling facilitated exposure of economic, social, technical and cultural 'connectivity' between key construction supply chain participants and their respective supply chain organizations.

Subsequent discussions and findings rely principally upon interview transcripts taken from these recorded semi-structured interviews. All interviews were conducted on a one to one basis. In addition, the data was supplemented with alternative sources of narrative data in the form of notes taken from other, unrecorded, meetings and interviews. Personal memo's documented after meetings and comments cited prior to or immediately after the semi-structured interviews are also drawn upon.

Theoretical sampling resulted in data being collected from seven large construction contracting organizations, three first tier construction service providers and three client bodies/representatives and one specifically identified procurement professional/consultant, see table 2 . These organisations feature prominently within industry league tables (Rogers, 2010) and were understood to be at the forefront of industry best practice. A number of limitations to the research are readily acknowledged. Notable exclusions from the research profile are overseas organizations, specific housebuilding companies and, small and medium sized contractors (SME's). Several of the participating companies however manage a diverse portfolio of commercial interests. This includes overseas construction activity and organizational subsidiaries operating within the UK housebuilding market.

Table 2. Summary of Company Classification, Main Activities and Participants

\begin{tabular}{|c|c|l|c|}
\hline COMPANY & $\begin{array}{c}\text { CLASSIFICATION } \\
\& \text { MAIN ACTIVITIES }\end{array}$ & $\begin{array}{l}\text { ORIENTATION } \\
\text { MEETING }\end{array}$ & $\begin{array}{c}\text { SEMI-STRUCTURED INTERVIEW } \\
\text { PARTICIPANTS }\end{array}$ \\
\hline
\end{tabular}




\begin{tabular}{|c|c|c|c|}
\hline & & - $\quad$ PARTICIPANTS & \\
\hline 1 & $\begin{array}{l}\text { Main Construction Contractor } \\
\text { Activities include: Construction / } \\
\text { Properties / Design / Facilities } \\
\text { Management / Services } \\
\text { Engineering / Plant }\end{array}$ & Regional Director & $\begin{array}{l}\text { a/ } \text { Construction Director (Health) } \\
\text { b/ Project Manager } \\
\text { c/ Senior Project Surveyor } \\
\text { d/ Design Manager } \\
\text { e/ Health Lead } \\
\text { f/ Health Project Director } \\
\text { g/ Regional Preconstruction Manager }\end{array}$ \\
\hline 2 & $\begin{array}{l}\text { Main Construction Contractor } \\
\text { Activities include: Construction / } \\
\text { Asset and FM / PPP / Consultancy }\end{array}$ & Supply Chain Manager & $\begin{array}{l}\text { a/ Chief Buyer } \\
\text { b/ Operations Director }\end{array}$ \\
\hline 3 & $\begin{array}{l}\text { Main Construction Contractor } \\
\text { Activities include: Infrastructure / } \\
\text { Construction / Support Services / } \\
\text { Project Management Services }\end{array}$ & Head of Supply Chain & $\begin{array}{l}\text { a/ Commercial / Supply Manager } \\
\text { b/ Divisional Supply Chain Manager } \\
\text { c/ Head of Procurement }\end{array}$ \\
\hline 4 & $\begin{array}{l}\text { Main Construction Contractor } \\
\text { Activities include: Construction / PFI } \\
\text { / Support Services / Consultancy }\end{array}$ & Framework Manager & \\
\hline 5 & $\begin{array}{l}\text { Main Construction Contractor } \\
\text { Activities include: Construction / } \\
\text { Utilities / Civil Engineering / Local } \\
\text { Authorities / Central Government / } \\
\text { Financial Services }\end{array}$ & $\begin{array}{l}\text { Safety, Sustainability \& } \\
\text { Compliance Manager }\end{array}$ & \\
\hline 6 & $\begin{array}{l}\text { Main Construction Contractor } \\
\text { Activities include: Construction / } \\
\text { Infrastructure / PPP / FM / Social } \\
\text { Housing }\end{array}$ & $\begin{array}{l}\text { Director of Business } \\
\text { Development }\end{array}$ & $\begin{array}{l}\text { a/ General Manager } \\
\text { b/ Commercial Director }\end{array}$ \\
\hline 7 & $\begin{array}{l}\text { Main Construction Contractor } \\
\text { Activities include: Construction / } \\
\text { Housing / PPP }\end{array}$ & Partnership Manager & a/ Partnership Manager \\
\hline 8 & $\begin{array}{l}\text { Specialist Service Provider } \\
\text { Activities include: Buildings / } \\
\text { Energy / Environment / Industry / } \\
\text { Mining / Transport / Infrastructure }\end{array}$ & Technical Director & $\begin{array}{l}\text { a/ Associate Director } \\
\text { b/ Technical Director (Production) } \\
\text { c/ Associate Director (Framework) }\end{array}$ \\
\hline 9 & $\begin{array}{l}\text { Specialist Service Provider } \\
\text { Activities include: Architecture / } \\
\text { Planning / Interior Design / } \\
\text { Landscape Design / Urban Design }\end{array}$ & Director & $\begin{array}{l}\text { a/ Divisional Director } \\
\text { b/ Divisional Director } \\
\text { c/ Design Consultant }\end{array}$ \\
\hline 10 & $\begin{array}{l}\text { Specialist Service Provider } \\
\text { Activities include: Facilities Services } \\
\text { / IT Services / Engineering Services } \\
\text { / Offsite Manufacture / Integrated } \\
\text { Services }\end{array}$ & & a/ Director \\
\hline 11 & $\begin{array}{l}\text { Client / Client Representative } \\
\text { Responsibilities include: Public } \\
\text { Sector (NHS) Estates \& Facilities } \\
\text { Expertise }\end{array}$ & $\begin{array}{l}\text { Deputy Director, } \\
\text { Strategic Planning \& } \\
\text { Construction }\end{array}$ & $\begin{array}{l}\text { a/ Assistant Director } \\
\text { b/ Framework Manager } \\
\text { c/ Framework Manager }\end{array}$ \\
\hline 12 & $\begin{array}{l}\text { Client / Client Representative } \\
\text { Responsibilities include: Public } \\
\text { Sector Estates (Local Authority) \& } \\
\text { Facilities Expertise }\end{array}$ & & a/ Contract Strategy Manager \\
\hline 13 & $\begin{array}{l}\text { Client / Client Representative } \\
\text { Responsibilities include: Public } \\
\text { Sector Estates (NHS) \& Facilities } \\
\text { Expertise }\end{array}$ & & $\begin{array}{l}\text { a/ Capital Projects Advisor } \\
\text { b/ Capital Projects Advisor }\end{array}$ \\
\hline 14 & $\begin{array}{l}\text { Procurement Consultant } \\
\text { Activities include: Consultancy / } \\
\text { Education / Author }\end{array}$ & $\begin{array}{l}\text { Head of Logistics } \\
\text { Research Centre }\end{array}$ & \\
\hline
\end{tabular}

\section{Coding Procedures}


Interviews transcripts and notes were coded and recoded on an ongoing basis using the qualitative analysis software package NVivo version 8. NVivo software is widely used and supported by the qualitative research community (Walsh, 2003, Crowley et al., 2002). Data collection could not be disassociated from the Straussian methodology adopted in that; the researchers did not initially collect data with an 'empty head'.

The semi structured interview was guided by the 'axial' codes and 'sub-themes' that emerged from the orientation meetings. New issues and headings emerged inductively from the ongoing data analysis and iteration between data and literature formed a more detailed and structured set of selective codes. The interviews, analysis and iteration continued until the data had been distilled sufficiently to enable comprehension (Loosemore, 1999). Although a largely arbitrary figure and at risk of a messy "drift towards positivism" (Suddaby, 2006 p.639), comprehension and by extension saturation is thought to be achieved between 8 and 24 interviews (Goulding, 1998). The 'field' data gathering phase ceased at eleven orientation meetings and twenty-eight semi-structured interviews.

Disaggregation of the axial codes (selective coding) disclosed concepts and categories that traversed organizational boundaries and individual stakeholder interests. Key categories emerging from the data included language, partnering, the quasi-firm and (absence of) supply chain champions. Supply chain language was significant .The homogeneity in linguistic phrasing was striking and largely coalesced around the notion of construction framework agreements. A foremost phrase depicting the imagery and symbolism of construction framework agreements was 'partnering philosophy'. Whilst the expression 'partnering philosophy' was a recurrent 
theme across the significant majority of informants, markedly its context remained largely rooted in construction framework agreements and the client-led supply chain.

In contrast to 'partnering' and client-led construction framework agreements, the notion of the quasi-firm emerged out of the literature (see Eccles, 1981, Reve and Levitt, 1984) and contractor-led supply chain management action, interaction and emotion. Again language was pivotal. Analysis of both language and practice disclosed mechanisms of both normative and mimetic behaviour regarding the implementation of category management protocols, see table 3. According to Stuart (1997), category management represents the first staging post on the route to supply chain management maturation. Four of the seven main contractors $(57 \%$ of the research sample) use explicit category management protocols.

Table 3. Category Management and emergence of the quasi-firm

\begin{tabular}{|c|c|c|c|c|}
\hline $\begin{array}{l}\text { Category } \\
\text { Management }\end{array}$ & $\begin{array}{l}\text { Contractor } \\
\text { A: Labels }\end{array}$ & $\begin{array}{l}\text { Contractor } \\
\text { B: Labels }\end{array}$ & $\begin{array}{l}\text { Contractor } \\
\text { C: Labels }\end{array}$ & $\begin{array}{l}\text { Contractor } \\
\text { D: Labels }\end{array}$ \\
\hline LEVEL 1. & $\begin{array}{c}\text { CAT. } 1 \\
\text { Supplier }\end{array}$ & Green & $\begin{array}{l}\text { Preferred } \\
\text { Supplier }\end{array}$ & $\begin{array}{c}\text { Full } \\
\text { Partner }\end{array}$ \\
\hline LEVEL 2. & $\begin{array}{l}\text { CAT. } 2 \\
\text { Supplier }\end{array}$ & Amber & $\begin{array}{l}\text { Approved } \\
\text { Supplier }\end{array}$ & $\begin{array}{c}\text { Provisional } \\
\text { Partner }\end{array}$ \\
\hline LEVEL 3. & $\begin{array}{l}\text { CAT. } 3 \\
\text { Supplier }\end{array}$ & Red & $\begin{array}{l}\text { Pre-Approved } \\
\text { Supplier }\end{array}$ & $\begin{array}{c}\text { Probationary } \\
\text { Partner }\end{array}$ \\
\hline
\end{tabular}

The role of management and the identification of the selective code 'supply chain champions' emerged primarily as a result of contrasting yet telling statements from two research participants working for the same parent organization:

Informant 3b, "my job title is Supply Chain Manager and my background was originally in procurement". 
Informant 3c, "supply chain manager for me would have

been a more appropriate role but business decided

they wanted to call me a procurement manager."

Intrigued by the underlying rationale for such divergent actions prompted a review of informant job titles. Subsequent appraisal of the occupational status of the twenty eight interviewees, notably all had been peer identified as having a key role to play in the development and diffusion of supply chain management, disclosed only two supply chain manager(s). Despite increasing industry awareness and rhetorical supply chain management strategies, data analysis suggests scant engagement with substantive change management techniques.

\section{Specific I Non Specific Procedures}

In contrast to Glaser, a Straussian approach to grounded theory sanctions a degree of interpretative latitude and creativity (Denk et al., 2012). Whilst the research process adopted retains a clear focus on the phenomenon under scrutiny; namely supply chain management, some procedural steps in the research process may be omitted. This is permissible under a Staussian interpretation. For example 'open coding' was not used. The initial process of open coding assists with early conceptual development by connecting key phrases with the phenomenon under investigation (Goulding, 1999). However in place of open coding, influences of self and extant literature were drawn upon to inform and explore industry supply chain management demands and desires via orientation interviews. In response to the orientation meetings 'axial coding' namely, background / context, supply chain management, framework agreements and stakeholder interpretation emerged. In addition, the deep cognitive processes and developing schemata resulting from 
constant comparison remain largely hidden. Crucially, the resultant core category is made explicit; namely, institutionalism and the over-arching theme of non-adoption.

\section{Core Category}

According to Mello and Flint (2009 p.211), the definition of core category is the "central category of the phenomenon about which the theory is concerned". The identification of the core category explains the behaviour, actions, interactions and emotions identified in the research findings. The core category emerges from the data, grounded in the iterative-inductive process of knowledge assimilation and creativity and reflected in the constant iteration between literature and data. Significantly, the core category emerges from the analysis and is not identified beforehand (Denk et al., 2012). Institutionalism and the over-arching theme of nonadoption emerged from the data as the core category, see figure 1.

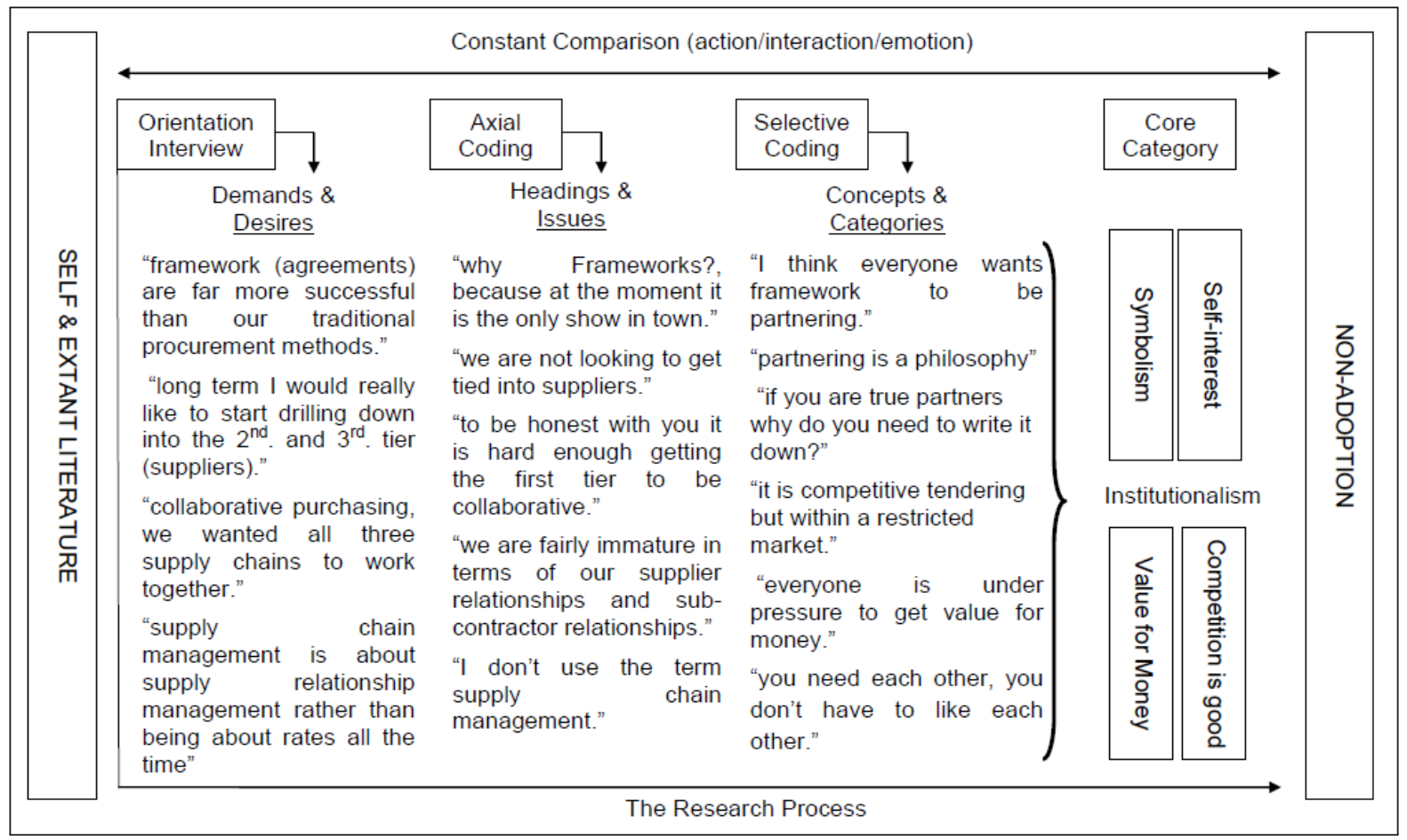

Figure 1. Examples of informant statements, coding, analysis and core category

\section{Evaluation Criteria}


The evaluation criteria for grounded theory are widely debated. Whereas Glaser cites four characteristics essential to evaluation namely; fit, workability, relevance and modification (Denk et al., 2012), Corbin and Strauss (2008) adopt a more interpretative perspective. Although the list is sizable, three key criterions include reliability, generalizability and transparency.

Reliability is reached when it is judged probable that future studies would elicit the same or similar outcome(s) given parity in terms of situation. In the context of qualitative research reliability is largely perceived as a measure of confidence that the results would be replicated under similar circumstances. Given the 'institutionalization' of behavioural patterns exhibited, there exists considerable confidence that comparable supply chain management studies would elicit similar action, interaction and emotions.

Whilst generalization is not the raison d'être of grounded theory research (Corbin and Strauss, 2008), there remains considerable scholarly pressure to demonstrate generalizability (Glaser, 2007). Typically, generalization relates to extending the implications of the research findings beyond the strict parameters of the study. In this context, research findings are generalizable insofar as they provide a wideranging statement on the action, reaction and transaction of supply chain practice in construction.

Transparency relates to the research process being made explicit, see figure 2 . According to Denk et al (2012), transparency is enriched by addressing six dimensions of grounded theory methodology; namely, emergence and researcher distance, theory development, coding procedures, specific / non-optional procedures, core category and evaluation criteria. Finally, according to Stern (2010), the true 
litmus test of grounded theory is that explanations for the behaviour, actions, reactions and emotions make sense.

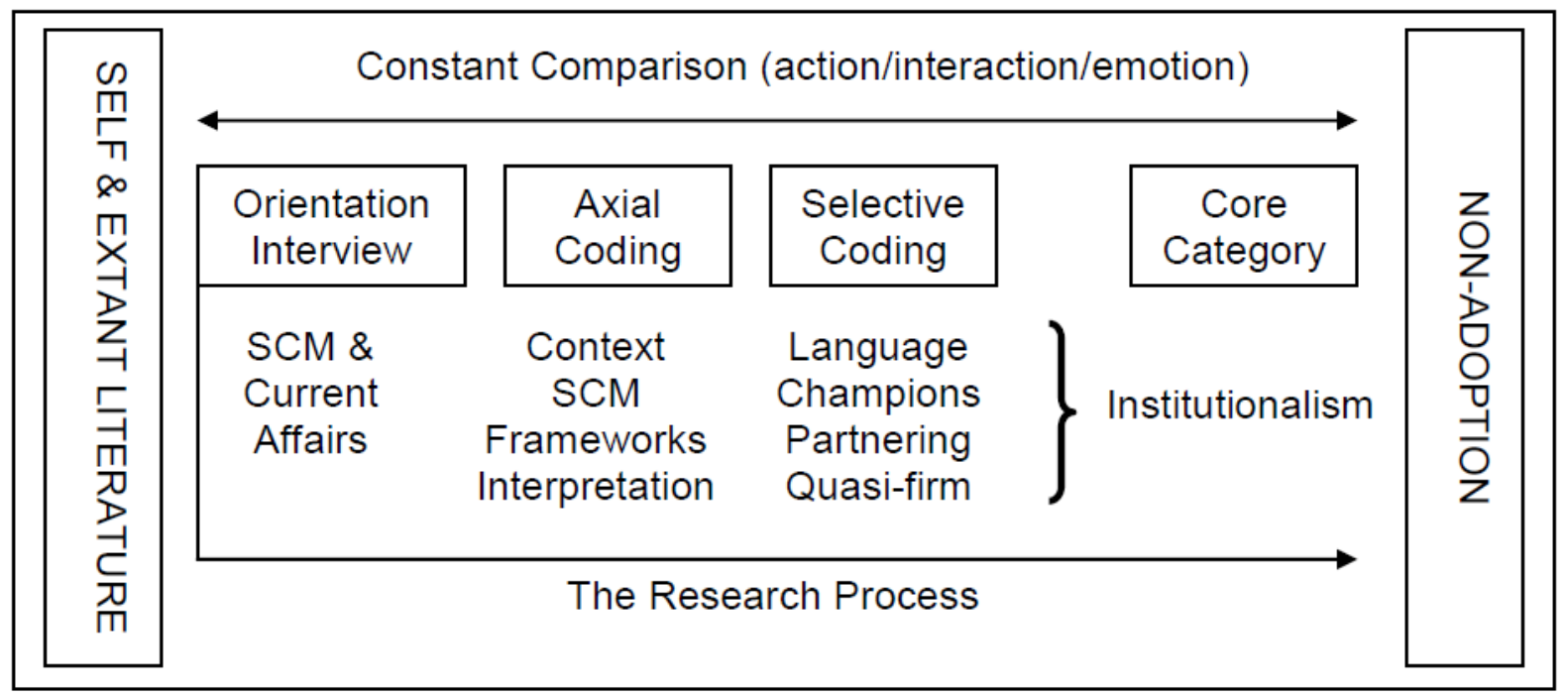

Figure 2. Summary of the research process

\section{The role of Institutional theory}

Institutional theory (see Barley and Tolbert 1997; DiMaggio and Powell 1991; Hung and Whittington 1997; Orrù 1991) has its theoretical foundation in sociological theory where an institution is typically defined as an organized, established, procedure (Jepperson 1991). Proponents of institutional theory advocate three distinct mechanisms of diffusion: namely, coercive, normative and mimetic (DiMaggio and Powell, 1983, Scott, 2008). Coercive mechanisms relate to powerful institutions, typically regulative institutes such Government that have both the legislative authority and organizational capital to compel others to comply. Normative mechanisms of diffusion are morally governed binding expectations that reflect and reinforce ongoing refinements to practices. Mimetic mechanisms are influenced by the perceived success of others and convey an operational legitimacy (Meyer and Rowan, 1977). 
Drawing upon institutional theory, innovation diffusion is argued to pass through five key staging posts: namely, knowledge, persuasion, decision, implementation and confirmation (Rogers, 1983). This is complemented by Larsen (2005) with a contextually sensitive model of innovation diffusion set within the parameters of the UK construction industry. Larsen (2005) draws upon three concepts of innovation diffusion namely; cohesion, structural equivalence and thresholds. Cohesion relates to the concept of "being connected" (Scott, 2008 p.165) where "the more frequent and empathic the communication", the greater the probability of social contagion (Burt, 1987 p.1289). Structural equivalence on the other hand relates to "being similar", as opposed to "being connected" (Scott, 2008 p.165). Very often the assembled parties involved will exhibit strikingly similar characteristics. Threshold suggests that adoption may be based upon social norms as opposed to notions of 'best practice' (Granovetter, 1985). Diffusion threshold is simply the 'tipping point' where perceived benefits outweigh perceived costs of non-adoption (Granovetter, 1978).

The translation of innovation is argued to follow a process of diffusion and institutional change that leads to "disruptive but necessary" adjustments to organizational routine (Brown and Duguid 1996 p. 59). In constructing explanations for the development and diffusion of supply chain management in construction, institutions, institutional theory and innovation diffusion models described above were found to be instrumental in making sense of "how social choices are shaped, mediated and channelled by the institutional environment" (Wooten and Hoffman, 2008 p.130). Institutionalism and by extension institutional change underpins to a large extent the themes discussed below and the development of explanations. 


\section{Key emergent themes and discussion}

What emerged from the iterations between data and literature was a number of pivotal themes central to explanations concerning the diffusion and development of supply chain management in construction. These themes resonate with a number of significant and highly relevant organisation theories. The following findings and discussions draw upon these themes and attendant theories in order to make sense (see Stern, 2010) of, and explain, the development and diffusion of supply chain management in construction.

\section{The translation of and meaning ascribed to language}

The findings from the research clearly demonstrate that the terms supply chain management, supply chains and integrated supply chains, collaboration, integration, partnering and trusting relationships form and are used to help frame practitioners' descriptions of supply chain management. These terms have therefore successfully spread across UK construction organisations (see Sahlin and Wedlin, 2008). They were frequently used to describe aspects of construction activity reflective of O'Brien et al's. (2009) supply chain themes of production, organisation and information technology. Language associated with Lean thinking, Building Information Modelling (BIM) and strategic alliances such as partnering were typically used by practitioners to describe supply chain management activities. This terminology formed the foundation of practitioners' interpretations of the reach and impact of supply chain management on construction practices or, as evidence of supply chain management per se. There is undoubtedly significant awareness of and clear evidence of the diffusion of supply chain management terminology. 
In describing the services, approaches and practices underpinning these activities, practitioners had clearly been persuaded of the need to complement and adapt their 'traditional' language. This adapted language was in particular institutionalised through client led procurement approaches that coalesced around the use of construction 'framework agreements', alliances and partnering. The procurement and management of contractor led construction services and product providers was also replete with a surprisingly consistent and common language that described processes of categorisation, performance measurement and accreditation; essentially supplier management. There is thus strong institutional support for diffusing supply chain management terminology via procurement approaches and explicit supplier management systems.

The 'novelty' of this adapted language is however debateable as the overwhelming majority of informants simultaneously drew upon an interesting fusion of the terms and language associated with supply chain management, design and build and partnering. Indeed, within the language used, practitioners drew little or no distinction between supply chain management and partnering. This inability to separate supply chain management from partnering reflects a long standing and repeated concern within the literature (see Macbeth and Ferguson 1994, Fernie and Thorpe 2007). Rather than pointing towards an emphasis on 'holism', system of systems and networks, such interpretations concentrate upon the structure and management of dyadic relationships.

There is undoubtedly a significant chasm between the meanings ascribed to supply chain management by construction practitioners and the underlying assumptions of supply chain management in the literature. Meanings ascribed appear to be shaped by ongoing concerns and interests with diffusing and developing better dyadic 
relationships. Commercially at least, the adoption of the terminology per se may not necessarily bring rewards, its non-adoption however certainly courts punishment. Essentially it appeared widely accepted by practitioners that failure to reflect the terminology used by procurement agencies and policy would result in exclusion from the procurement process. Institutional pressure (see Bresnen and Marshall, 2001) has arguably persuaded and legitimised the adaptation and adoption of terminology by practitioners and organisations. Such persuasion is rooted in coercive mechanisms and associated punishments (see Scott, 2008) mobilised by public and private sector clients. Any 'tipping point' (Granovetter, 1978) in decisions to adopt supply chain management terminology therefore relate to an evaluation of costs associated with punishment for non-adoption. The language has therefore not just been highly socialized and politicized (Bresnen and Marshall, 2001) but also commercialized. In isolation of significant scrutiny on practice, the terminology has a symbolic purpose or value that can legitimately sit in isolation of substantive changes to practice.

Terminology has to some extent clearly been successfully diffused within the industry however, its translation and ascribed meanings appeared disconnected from views that supply chain management meant holistically managing chains or networks. Furthermore, these meanings appear to conflate supply chain management with partnering and emphasise dyadic relationships. The diffusion of terminology cannot therefore be assumed to be evidence of success in developing and diffusing supply chain management theory and practice.

Partial explanations for this non-adoption were related to a lack of resonance between industry stakeholder interests and policy directed change initiatives. These interests shape the way meanings are ascribed to supply chain management and act 
as a litmus test for relevance. Shaping and diffusing alternative dyadic relationships is arguably interpreted by practitioners to resonate with their concerns and thus highly relevant. The meanings ascribed to supply chain management terminology arguably act to reinforce and legitimise previous policy and initiatives associated with Latham (1994) and partnering (see Bennet and Jayes 1999) rather than supply chain management per se.

\section{Institutionalising change through champions}

In contrast to the widespread use of terminology, the data revealed that surprisingly few construction organizations have appointed senior supply chain management professionals. These positions and appointment are argued to act as innovation champions (Dulaimi et al., 2005) to institutionalise translations and transformation of supply chain management theory to practice. Their influence is firmly established in innovation diffusion theory (Sharma, 1999, Howell and Higgs, 1990) and according to Winch (1998 p.274), "the most consistent finding of research on innovation is that innovation needs champions". Thus, senior supply chain management positions that provide creative leaders (Bossink and Vrijhoef, 2011) and innovation champions (Winch, 1998, Leiringer and Cardellino, 2008) are indicative of the development of powerful institutions to support the process of translating and diffusing change. They provide coercion (see DiMaggio and Powell, 1983, Scott, 2008) and act to persuade practitioners to legitimately challenge, change and adopt alternative, or reinforce existing, practices.

Notably, in previous construction cases studies, Nam and Tatum (1997) demonstrate the pivotal 'championing' role senior designers, engineers and main construction contractors play in diffusing technical innovations. Such a role is therefore widely 
understood to be pivotal to institutionalising change in the construction industry. The predominant absence of 'champions' (Leiringer and Cardellino, 2008) means that the process of diffusing supply chain management practice is unlikely to pass beyond the first staging post outlined by Rogers (1983); knowledge. There is thus little institutional support to persuade and consequently, no need for practitioners to legitimise decisions to adopt supply chain management per se.

The findings above challenge the notion of supply chain management being wholly relevant to practitioners. Despite this, the following discussion focuses upon what practitioners considered the scope for supply chain management - dyadic relationships. Arguably, these have been actively shaped by what does resonate with industry practitioner's interests and the meanings they typically ascribed to supply chain management.

\section{Client led supply chains: reinforcing partnering}

Interpretations of supply chain management in construction were strongly connected to procurement approaches such as framework agreements. These are beginning to feature more strongly in the literature (see Tennant and Fernie, 2012) as their use increases (see RICS, 2010). As with all procurement routes (Rowlinson, 1999), they set out overarching rules and regulations (although not legally binding) and provide a setting within which clients and contractors explicitly agree to work together over multiple projects (Gruneberg and Hughes, 2004). Frameworks are broadly an institution with attendant rules that frame the basis of compliance, order, legitimacy and punishment. They are also reflective of what King and Pitt (2009) describe as client-led supply chains. 
Frameworks agreements create and legitimise clusters of organisations led by a Principal Supply Chain Partner (PSCP) (contractor) and associated Principal Supply Chain Member (PSCM) (consultants) that collectively compete with other clusters to pre-qualify for inclusion in the framework. The number of clusters chosen differs across frameworks but must then compete with each other for individual projects that form bundled streams of workload over a specified period. Notably, frameworks are subject to variations. Firstly, in some frameworks, cluster members had to be exclusive members of a single cluster. In others, organisations (consultants) could be members of two or more clusters. Some framework agreements involved three clusters whilst others could involve four or more. In some cases clusters were predominantly encouraged to compete and in others they were encouraged to 'share' and work together outwith projects. Furthermore, across public sector procurement agencies, the use of frameworks may or may not be mandatory.

Despite these local variations, frameworks were broadly interpreted by practitioners to increase integration and collaboration within the cluster, between the client and appointed clusters and to a limited extent between clusters. Both horizontal (within the cluster and between clusters) and vertical (between client and cluster) dyadic relationships formed the basis for extending emerging theories of 'triads' (Choi and Wu, 2009) and long standing theories of governance and transaction costs (Williamson 1979). These theories help to frame discussions and explain the balance sought between competition and collaboration by the client and, the emergence of clan forms of governance within clusters. Prior to these discussions though, it is necessary to discuss the role of the market and dynamic shifts in power as markets change. This was found to be hugely influential within framework agreements and to deepen understanding of supply chain management in construction. 
The recent recession and associated austerity measures placed on government procurement (O'Sullivan, 2011) were widely interpreted by practitioners to have legitimised renegotiation of previously agreed costs, terms and conditions within framework agreements. This orientation to dynamic markets is perhaps inescapable as public procurement agencies are incentivized to achieve 'value for money' for taxpayers. Consequently, demonstrating competitive market prices remains a dominant legitimising institution within framework agreements. Practitioners (clients, PSCP and PSCM) interpretations of supply chain management were clearly tempered by an understanding that 'value for money' inevitably formed a strong feature of the 'rules of the game' (Scott 2008). Renegotiation and changes to the terms of the 'agreement' were inevitably understood as part of the 'game' and to some extent foreseeable and unavoidable. Whilst frameworks as an institution do therefore legitimise convenient construction alliances (Cox et al 2004) they are similarly suppressed by a rational interpretation that power within the markets continually shift, is dynamic and thus likely to change over time. Interpretations of supply chain management that attach themselves to frameworks are thus by extension conceding to a bounded perspective of holistic management, integration and collaboration. Bounded by 'value for money'.

The emergence of clans

Despite this, framework agreements were understood to have played a significant role in the emergence of an alternative governance structure; clans. Described by Ouchi (1981 p.83) as an "intimate association of people engaged in economic activity", a clan form of organizational governance is clearly distinguishable by 
enduring commercial relationships, highly socialised marketplace and local culture (Ouchi, 1980, Wilkins and Ouchi, 1983). What emerged from the iterations was a client-led, framework orientated community, a clan, where clusters were interpreted by practitioners to have significant shared economic, social and technological interests in the strategic alliances formed vertically with clients and horizontally within the cluster. Clients are certainly understood to be leading the legitimisation of alliances through frameworks but, within the data there lacked any significant emphasis on legitimising the management of a 'chain' of organisations. Clan governance in this sense relates to the agreement between clients and 'chosen' clusters of organisations. The agreement legitimises informal and tacit rules and regulations between clients and clusters and also within and between the clusters themselves.

Symbolic of growing commercial solidarity, the absence of litigation within clusters and between clusters and clients was interpreted to be a significant indicator of success. Indeed, "early warnings", "sensible agreements" and "transparency", underpinned a strong commitment within the emergent clan to resolve issues without resorting to the primacy of explicit contract rules and regulations. This, coupled with efficiencies derived from tendering was interpreted to have reduced transaction costs within the clan. However, to coerce competitive tension, under certain conditions, the client reserved the right to procure outside the framework - they were understood to remain mindful of overly cozy relationships (Latham, 1994) and any possible erosion of 'value for money'.

This reveals a schism within the client regarding the use of framework agreements. On the one hand, clients used frameworks to achieve the benefits associated with clan forms of governance between themselves and the clusters. On the other, they 
were perceived to be fearful of increased power emerging from the governance of clans within cluster and thus reserved the right to procure outwith the confines of the framework. This complex balancing act connected very strongly with the theory of 'triads' and the myriad of options for managing what others have termed coopetition (see Wilhelm, 2011).

Triads to explain frameworks

The dyadic relationship between a cluster and a client or, between organisations within a cluster in framework agreements are contingent upon, and embedded within, a larger network with arguably, a past, present and future. Firstly, dyadic relationships between clients and a particular cluster are contingent upon the dyadic relationship between the client and other clusters. If we consider just two clusters then there exists nine ways in which collaboration and integration may be manipulated by triadic relationships (Choi and Wu, 2009). This is significantly more complex where framework agreements draw upon more than two clusters to deliver projects.

Secondly, the dyadic relationship between client and the main contractor in the cluster is contingent upon the dyadic relationships within the cluster between main contractor and consultants. By creating clusters within the framework agreement, clients are effectively developing 'triadic sourcing' strategies (Dubois and Fredrickson 2008) and relationships that provide a legitimacy for organisations in a cluster to collaborate. This is contingent upon, and made significantly complex by, rules within frameworks that may or may not limit cluster organisations being exclusive to a single cluster. 
Thirdly, PSCP and PSCM are simultaneously embedded in particular framework agreements and clusters at the same time as being embedded in numerous other customer and supplier networks, framework agreements and clusters. Lastly, clients and organisations within clusters have all been embedded in previous networks that, along with current networks, shape future triadic and dyadic relationships. Current relationships in frameworks are thus contingent upon past project and also the 'shadow of future workload' (Tennant and Fernie 2012).

Drawing upon the first two characteristics of triads described above, clients can clearly influence and control the 'rules of the game' through triadic relationships that involve themselves and individual clusters. However, framework agreements also use triadic sourcing strategies that lead to collaboration and integration between organisations within clusters. Whilst seeking to gain efficiencies from greater collaboration and integration within the cluster, clients cannot control how informal agreements evolve, emerge and impact upon power dynamics between client and cluster. Furthermore, in circumstances where communication between clusters is encouraged as the basis of learning, the client may also not be in a position to control the evolution and emergence of informal agreements between clusters that may rationally act to reduce client power.

To counteract any significant rise in cluster power, the data revealed that clients reserve the right to seek tenders from the open market at any point in time; the shadow of no workload continuity for the future. They also, as the data revealed, renegotiate, at any time, frameworks terms and conditions regardless of previous specified timescales for the agreement. Power dynamics engineered through triadic arrangements are thus constantly monitored within the confines of the framework and also set against the certainty of power dynamics that can be achieved by going 
to market. Explaining how and why clients seek to manage and control the supply chain is thus better served by an understanding of triadic relationships and not the contemporary emphasis on dyadic relationships in the construction supply chain management literature. Triads also provide a basis upon which to rest explanations for co-opetition and how clients seek to balance 'value for money' against models of collaboration and competition.

\section{Summary}

Whilst procurement routes such as frameworks are interpreted to have a powerful institutional role to play in diffusing change, they are similarly interpreted to be limited as the basis of mechanisms to rapidly coerce, normalise and mimetically change practice. Furthermore, frameworks agreements remain firmly rooted in the market. Thus, in a sector that has and continues to be subject to market fluctuations, frameworks compete with other powerful institutions, such as self-interest, competition and 'value for money' in coercing and persuading the adoption of alternative, or reinforcement of existing, procurement practices.

The emergence of clans from the data, and theories of governance to explain their emergence provide evidence that frameworks are instrumentally shaping alternative 'rules of the game' and that strategic alliances are beginning to achieve legitimacy. In doing so, their regulatory and normative power to persuade organisations to change practice is growing. However, clients' need to control networks within frameworks requires a turn to triadic relationships as a way to explain the paradox inherent in simultaneously encouraging collaboration whilst at the same time remaining wary of overly cozy relationships. Essentially, collaboration is good as long as it does not erode clients' existing power and ability to control. Their ability to control networks in 
frameworks is also limited to downwards triadic relationships with clusters comprising main contractors and consultants. Despite frameworks being at the zenith of progress towards supply chain management in construction, control of any attendant network does not extend to a vertical 'chain' of organisations. Frameworks are therefore more reflective of client-led partnering and not supply chain management.

\section{Contractor led supply chains: the quasi-firm}

The data revealed that embedded within large construction contractors is the widespread use of formalized pre-qualification questionnaires (PQQ), key performance indicators (KPI's) and benchmarking to categorise and accredit suppliers. The ambition of these institutionalised systems was widely interpreted to be concerned with pro-actively managing interdependencies between the first tier (main contractor) and second tier service and product providers. There is considerable similarity between these institutionalised systems and the use of framework agreements by clients but, these systems do not provide any significant certainty of workload continuity.

The systems institutionalise practices between main contractors and their suppliers and emphasise dyadic relationships. Within frameworks, these suppliers lie outwith those that form the relationships between consultants and main contractors in clusters. Unlike framework agreements, these systems do not legitimise integration and collaboration horizontally across a tier of organisations. There are also no exclusivity clauses and thus tier two suppliers can be members of multiple supplier management systems and feed into multiple framework clusters. Unlike framework agreements, transactions are explicitly conceded to be rooted in the marketplace 
and are thus subject to market dynamics and ongoing shifts in power between buyer and supplier. Interestingly, whilst the language and labels varied in the implementation of category management, the description and interpretation of these institutionalised systems and remained constant across main contracting organisations. This reflected a normative and mimetic mechanism at play within the construction industry regarding the evolution of such systems.

Supplier management systems frequently described tendering criteria that deviated from costs alone but, these deviations were also understood to carry little weight. As such, lowest cost was repeatedly cited as the key criteria for selection and succinctly described by one informant as the continuation of traditional competitive tendering but within a restricted market. The metaphor of 'chain' is redundant here in managing suppliers. These systems, policies and procedures are undoubtedly understood by practitioners to provide a formal institution to shape practice and can be explained by describing their purpose as simply making formal those tacit systems previously observed and described by Eccles (1981) as the quasifirm.

These new formalised institutions, understood by practitioners to relate to supply chain management, do not provide a strong basis upon which to persuade and coerce organisations to adopt greater integration and collaboration. Main contractors have limited ability to control these networks and did not mobilise triadic sourcing arrangements. They also do not see the sense in moving towards alternative power dynamics by mobilising explicit framework agreements with their suppliers but did nonetheless relate to governance through supply networks as identified by (Dubois and Gadde, 2000). 
As an institution, supplier management systems set out to formally legitimise existing practice where transactions remain firmly rooted in the marketplace. Influence is limited to the dyadic relationships and more accurately reflective of an institution to support and legitimise simplistic purchasing strategies. They are however simply explained through the use of network governance structures, the quasifirm (Eccles 1981) and power dynamics within markets. Like framework agreements, as an institution these systems are undoubtedly interpreted to resonate with supply chain management theory but, on their own cannot persuade and diffuse integration, coordination, collaboration and efficiencies across a supply chain.

\section{Non-adoption of Supply Chain Management}

This study found that a language of supply chain management in construction had evolved and was widely used. Contextually, knowledgeable practitioners had carefully translated the rhetoric from policy (see Skitmore and Smyth, 2009) to legitimise the drive to achieve efficiencies from adopting partnering and category management. Institutionalisation of the language was a "disruptive but necessary" (Brown and Duguid, 1996 p.56) commercial adjustment and manifested itself within the development of further formal institutions such as framework agreements and supplier management systems. Given these connections, framework agreements, not surprisingly, dominantly attempt to legitimise partnering and supplier management systems and formally legitimise explicit yet simple purchasing strategies. Neither of these institutions attempts to legitimise practice that develops integration and collaboration between vertical chains of organisations and the development of competing supply chains. 
Frameworks do however legitimise clan forms of governance between clients and a limited number of clusters. Such governance is also evident between organisations within the clusters themselves. Drawing upon triad theory, powerful clients are able to engineer and control predominantly priced based competition between clusters. They cannot however control the shifting dynamics of power that evolve from the use of triadic sourcing arrangements that result in greater collaboration and integration within clusters. Engaging with the theory of triads helps to explain the objectives of framework agreements to both gain efficiencies from collaboration and at the same time limit any change in clients' purchasing power. Frameworks also connect with and influence the development of explicit supplier management systems used by main contractors that make transparent those previously tacit relationships and practices known as the quasifirm. A network form of governance at this interface reflects and reinforces the legitimacy of practices associated with the quasifirm.

Central to the use of frameworks and governance structures were competing institutions such as the pro-market economy and 'value for money'. These remain strong regulative, normative and to some extent cultural institutions within the construction sector and place severe restrictions on the widespread and successful diffusion of supply chain management theory and practice. Furthermore, the development of innovation champion positions and roles within organisations as a regulative and normative institution to legitimise the adoption of alternative innovative supply chain management (or partnering) practice are largely absent.

Limitations to the study and the explanations above should be noted. Firstly, data for the study was predominantly derived from interviews rather than other data collection methods. Future studies may benefit from the deployment of other methods or mixed methods approaches as well as from deploying longitudinal research and a greater 
sample size and/or a broader engagement with industry practitioners. These clearly, as in all studies of this nature limit the generalizability of the interpretations and explanations offered. However, the research benefits from its highly contextualised approach and the generation of grounded understanding that reflect the daily realities of practitioners' translation of supply chain management to their practices. Secondly, the sample reflects downstream organisations in the supply chain. Future research may be necessary to explore upstream. Notably, the snowball sampling technique did not direct us towards those organisations further upstream.

\section{Conclusions}

Notwithstanding a decade of policy development, academic debate and industry engagement, the development and diffusion of supply chain management in UK construction can best be described as non-adoption. Individually, the sophisticated language, the limited recruitment of innovation champions and emergent patterns of institutional change denote progress. Collectively however, they do not represent a substantive adoption of supply chain management in construction. Acknowledging the institutional correlation between symbolism and legitimacy (Meyer and Rowan, 1977, DiMaggio and Powell, 1991) and the concept of diffusion threshold (Granovetter, 1985), it remains impossible to ascertain if 'modification of practice' is driven by an ideological conviction in the perceived benefits of supply chain management or simply an instrumentally rational adjustment in response to maintaining commercial currency within the wider construction community. In summary, supply chain management assumptions are neither widespread nor wholly adopted by organisations in the UK construction industry. It is questionable if they ever will and debateable if they ever should. 
Consequently, whilst supply chain management continues to dominate change initiatives (see O'Brien et al., 2009, Egan, 1998, Wolstenholme, 2009, Meng et al., 2011) its diffusion will continue to be criticised as being slow, patchy and inconclusive. The findings reinforce this criticism and, by drawing upon institutions, the use of language, power, innovation champions, governance theory, triad theory and the quasifirm provide grounded explanations for the non-adoption of supply chain management.

The findings challenge the simplistic assumption that chains and networks of organisations can be holistically managed and controlled by any single organisation or institution in the construction industry. Instead, what the findings present is the basis for engaging in debate and discussion concerning the non-adoption of supply chain management. Understanding current and evolving industry practice from this fresh perspective can be used as the basis for further theory building to explain what change is possible, what such change may bring and the road to achieving such change. Consequently, the findings can also be drawn upon to inform attempts to further develop evidence based policy making within the construction industry.

\section{Acknowledgements}

This has been left blank until final editing.

\section{References}

ANDERSEN, P.H., \& KRAGH, H. (2010) Sense and sensibility: Two approaches for using existing theory in theory-building qualitative research, Industrial Marketing Management, 39, 49-55

ASTLEY, W. G. (1984) Subjectivity, Sophistry and Symbolism in Management Science. Journal of Management Studies, 21, 259 - 272. 
BARLEY, S. R., and TOLBERT, P.S. (1997) "Institutionalization and structuration: studying the links between action and institution." Organization Studies, 18(1), 93117.

BEACH, R., WEBSTER, M. \& CAMPBELL, K. M. (2005) An evaluation of partnership development in the construction industry. International Journal of Project Management, 23, 611 - 621.

BENNETT, J. \& JAYES, S. (1998) The Seven Pillars of Partnering: A Guide to Second Generation Partnering, Reading Construction Forum, The University of Reading, UK

BERR (2004) Supply Chain Management. London, Constructing Excellence.

BORGSTRÖM, B. (2012) Towards a methodology for studying supply chain practice. International Journal of Physical Distribution \& Logistics Management, Vol. 42(8), $843-862$.

BOSSINK, B. A. G. \& VRIJHOEF, R. (2011) Innovation Management in the Construction Supply Chain. IN O'BRIEN, W., J., FORMOSO, C., T., VRIJHOEF, R. \& LONDON, K. (Eds.) Construction Supply Chain Management Handbook. London, Taylor and Francis Group.

BOURGEOIS III, L. J. (1979). Toward a method of middle-range theorizing. Academy of Management Review, 4, 443-447.

BRESNEN, M. \& MARSHALL, N. (2001) Understanding the diffusion and application of new management ideas in construction. engineering, Construction and Architectural Management, 8, 335 - 345.

BRESNEN, M. (2009) Learning to Co-operate and Co-operating to Learn: Knowledge, Learning and Innovation in Construction Supply Chains. IN PRYKE, S. (Ed.) Construction Supply Chain Management Concepts and case studies. Oxford, Wiley-Blackwell.

BRISCOE, G. \& DAINTY, A. (2005) Construction supply chain integration: an elusive goal? Supply Chain Management: An International Journal, 10, 319 - 326.

BRISCOE, G., DAINTY, A., MILLETT, S. J. \& NEALE, R. H. (2004) Client-led strategies for construction supply chain improvement. Construction Management and Economics, 22, 193 - 201.

BROWN, J. S. \& DUGUID, P. (1996) Organizational Learning and Communities of Practice: Towards a Unified View of Working, Learning, and Innovation. IN COHEN, M. D. \& SPROULL, L. S. (Eds.) Organizational Learning. London, Sage. 
BRYANT, A. \& CHARMAZ, K. (2010) Grounded Theory in Historical Perspective: An Epistemological Account. IN BRYANT, A. \& CHARMAZ, K. (Eds.) The SAGE Handbook of Grounded Theory. London, SAGE Publications Ltd.

BURT, R. S. (1987) Social contagion and innovation: cohesion versus structural equivalence. American Journal of Sociology, 92, 1287 - 1335.

CABINET OFFICE (2011) Government Construction Strategy, Cabinet Office, London.

CAIRNS, G. (2008). Advocating an ambivalent approach to theorizing the built environment. Building Research \& Information, 36(3), 280-289.

CARTER, C. R. (2011) A Call for Theory: The Maturation of the Supply Chain Management Discipline. Journal of Supply Chain Management, 47, 3 - 7.

CHIMA, C.M. (2007) Supply-Chain Management Issues In The Oil And Gas Industry. Journal of Business \& Economics Research, 5(6), 27 - 36

CHOI, T. Y. \& WACKER, J. G. (2011) Theory Building in the OM/SCM Field: Pointing to the Future by Looking at the Past. Journal of Supply Chain Management, 47, 8 11.

CHOI, T.Y. \& WU, Z. (2009) Triads in supply networks: Theorizing buyer-suppliersupplier relationships. Journal of Supply Chain Management, 45(1), 8 - 25

CLEGG, S.R. \& BAILEY, J.R. (Eds) (2008) International encyclopedia of organization studies. Sage, Thousand Oaks, US.

CONSTRUCTING_EXCELLENCE (2005) Why use a framework agreement? , Constructing Excellence in the Built Environment.

CORBIN, J. \& STRAUSS, A. (2008). Basics of Qualitiative Research 3e, London, Sage Publications Inc.

COX, A. (1999) Power, value and supply chain management. Supply Chain Management: An International Journal, 4, 167 - 175.

COX, A., IRELAND, P. \& TOWNSEND, M. (2006) Managing in Construction Supply Chains and Markets, London, Thomas Telford.

COX, A., WATSON, G., LONSDALE, C. \& SANDERSON, J. (2004) Managing appropriately in power regimes: relationship and performance management in 12 supply chain cases. Supply Chain Management: An International Journal, 9, 357 371.

CROOM, S., ROMANO, P. \& GIANNAKIS, M. (2000) Supply chain management: an analytical framework for critical literature review. European Journal of Purchasing \& Supply Management, 6, 67 - 83. 
CROWLEY, C., HARRE, R. \& CLARE., T. (2002) Qualitative research and computing: methodological issues and practices in using QSR NVivo and NUD*IST. International Journal of Social Science Methodology, 5, 193 - 197.

DE BEUCKELAER, A., \& WAGNER, S. M. (2012). Small sample surveys: Increasing rigor in supply chain management research. International Journal of Physical Distribution \& Logistics Management, 42(7), 615-639.

DeHORATIUS, N., \& RABINOVICH, E. (2011) Field research in operations and supply chain management, Journal of Operations Management, 29, 371-375

DENK, N., KAUFMANN, L., CARTER, C.R. (2012). Increasing the rigor of grounded theory research - a review of the SCM literature. International Journal of Physical Distribution \& Logistics Management, 42(8), 742-763.

DEY, I. (2007) Grounding Grounded Theory: Guidelines for qualitative inquiry, Emerald, UK

DIMAGGIO, P. J. \& POWELL, W. W. (1983) The Iron Cage Revisited: Institutional Isomorphism and Collective Rationality in Organisational Fields. American Sociological Review, 48, 147 - 160.

DIMAGGIO, P. J. \& POWELL, W. W. (1991) Introduction. IN DIMAGGIO, P. J. \& POWELL, W. W. (Eds.) The New Institutionalism in Organisational Analysis. London, The University of Chicago Press.

DUBOIS, A. \& FREDRIKSSON, P. (2008) Cooperating and competing in supply networks: Making sense of a triadic sourcing strategy. Journal of Purchasing \& Supply Management, 14(3), 170-179

DUBOIS, A. \& GADDE, L.-E. (2000) Supply strategy and network effects purchasing behaviour in the construction industry. European Journal of Purchasing \& Supply Management, 6, 207 - 215.

DUBOIS, A., \& GADDE, L. (2002). The construction industry as a loosely coupled system: Implications for productivity and innovation. Construction Management and Economics, 20(7), 621-631.

DULAIMI, M. F., NEPAL, M. P. \& PARK, M. (2005) A hierarchical structural model of assessing innovation and project performance. Construction Management and Economics, 23, 565 - 577.

ECCLES, R. G. (1981a). Bureaucratic versus craft administration: The relationship of market structure to the construction firm. Administrative Science Quarterly, 26(3), 449-469.

ECCLES, R. G. (1981b) The Quasifirm in the Construction Industry. Journal of Economic Behavior and Organization, 2, 335 - 357. 
EDMONDSON, A. C., \& McMANUS, S. E. (2007), Methodological Fit in Management Field Research. Academy of Management Review, Vol 32 No 4 pp 1155-1179.

EGAN, J. (1998) Rethinking Construction. DETR.

FAIRCLOUGH, J. (2002) Rethinking construction innovation and research - a review of the government's R\&D policies and practices, Department for Transport and Industry, London

FELLOWS, R. \& LIU, A. (2003) Research Methods for Construction, Oxford, Blackwell Publishing.

FERNANDEZ-SOLIS, J. (2008). The systemic nature of the construction industry. Architectural Engineering and Design Management, 4(1), 31-46.

FERNIE, S. \& THORPE, A. (2007) Exploring change in construction: supply chain management. Engineering, Construction and Architectural Management, 14, 319 333.

FREDRIK NILSSON, B. G. (2012). Moving beyond the systems approach in SCM and logistics research. International Journal of Physical Distribution \& Logistics Management, 42(8), 764 - 783.

GAMMELGAARD, B., \& FLINT, D. (2012). Qualitative research in logistics and supply chain management: Beyond the justification for using qualitative methods. International Journal of Physical Distribution \& Logistics Management, 42(8/9), Editorial.

GLASER, B. G. \& STRAUSS, A. (1967) The Discovery of Grounded Theory: Strategies for Qualitative Research, New York, Aldine de Gruyter.

GLASER, B. G. (2002a) Conceptualization: On Theory and Theorizing Using Grounded Theory. International Journal of Qualitative Methods, 1, 23 - 38.

GLASER, B. G. (2002b) Constructivist Grounded Theory. Forum: Qualitative Social Research, 3, Art. 12.

GLASER, B. G. (2007) Doing Formal Theory. In: BRYANT, A. \& CHARMAZ, K. (eds.) The SAGE Handbook of Grounded Theory. London: SAGE

GOULDING, C. (1998) Grounded theory: the missing methodology on the interpretivist agenda. Qualitative Market Research: An International Journal, 1, 50 57.

GRANOVETTER, M. (1978) Threshold models of collective behaviour. The American Journal of Sociology, 83, 1420 - 1443.

GRANOVETTER, M. (1985) Economic Action and Social Structure: The Problem of Embeddedness. American Journal of Sociology, 91, 481 - 510. 
GREEN, S. \& MAY, S. C. (2003) Re-engineering construction: going against the grain. Building Research \& Information, 31, 97 - 106.

GREEN, S., FERNIE, S. \& WELLER, S. (2005) Making sense of supply chain management: a comparative study of aerospace and construction. Construction Management and Economics, 23, 579 - 593.

GREEN, S., KAO, C.-C. \& LARSEN, G. D. (2010) Contextualist Research:Iterating between Methods While Following an Empirically Grounded Approach. ASCE Journal of Construction Engineering and Management, 136, 117 - 126.

GREENWOOD, D. and WU, S. (2012) Establishing the association between collaborative working and construction project performance based on client and contractor perceptions, Construction Management and Economics, 30:4, 299 - 308.

GRUNEBERG, S. \& HUGHES, W. (2004) Construction Consortia: do they serve any real purpose? IN KHOSROWSHAHI, F. (Ed.) 20th Annual ARCOM Conference. Edinburgh, ARCOM.

HAIG, D. B. (1995) Grounded theory as scientific method. Philosophy of Education, $281-290$.

HALLDORSSON, A., KOTZAB, H., MIKKOLA, J. H., \& SKJØTT-LARSEN, T. (2007). Complementary theories to supply chain management. Supply Chain Management: An International Journal, 12(4), 284-296.

HARTMANN, A. \& CAERTELING, J. (2010) Subcontractor procurement in construction: the interplay of price and trust. Supply Chain Management: An International Journal, 15, 354 - 362.

HEATH, H. \& COWLEY, S. (2004) Developing a grounded theory approach: a comparison of Glaser and Strauss. International Journal of Nursing Studies, 41, 141 - 150.

HM TREASURY (2010) Infrastructure Cost Review: Main Report. London, TSO.

HOLTI, R., NICOLINI, D., SMALLEY, M. (2000) The handbook of supply chain management, CIRIA and The Tavistock Institute, London

HOOD, J. (2007). Orthodox vs. Power: The Defining Traits of Grounded Theory. In: BRYANT, A. \& CHARMAZ, K. (eds.) The SAGE Handbook of Grounded Theory. London: SAGE Publications Ltd.

HOWELL, J. M. \& HIGGS, C. A. (1990) Champions of technological innovation. Administrative Science Quarterly, 35, 317 - 341. 
HUNG, S.-C., and WHITTINGTON, R. (1997). Strategies and Institutions: A pluralistic account of strategies in the Tiawanese computer industry. Organization Studies, 18(4), 551 - 575.

INGIRIGE, B. \& SEXTON, M. (2006) Alliances in Construction: Investigating initiatives and barriers for long-term collaboration. Engineering, Construction and Architectural Management, 13, 521 - 535.

INNOVATION GROWTH TEAM (IGT) (2010) Low Carbon Construction: Final report, HM Government, London

JEON, Y.-H. (2004) The application of grounded theory and symbolic interactionism. Scandinavian Journal of Caring Sciences, 18, 249 - 256.

KAUFMANN, L. \& WHU, N. D. (2011) How to Demonstrate Rigor when Presenting Grounded Theory Research in the Supply Chain Management Literature. Journal of Supply Chain Management, 47, 64 - 72.

KETCHEN, D.J. \& HULT, G.T.M. (2011) Building theory about supply chain management: Some tools from the organizational sciences, Journal of Supply Chain Management, 47(2), 12 - 18

KING, A. P. \& PITT, M. C. (2009) Supply Chain Management: A Main Contractor's Perspective. IN PRYKE, S. (Ed.) Construction Supply Chain Management Concepts and Case Studies. Oxford, Wiley-Blackwell.

KORCZYNSKI, M. (1996) The Low-Trust Route to Economic Development: InterFirm Relations in the UK Engineering Construction Industry in the 1980s and 1990s. Journal of Management Studies, 33, 787 - 808.

KOSKELA, L. (2008) Is a theory of the built environment needed? Building Research \& Information, 36, 211 - 215.

KOTZAB, H., TELLER, C., GRANT, D. B., \& SPARKS, L. (2011). Antecedents for the adoption and execution of supply chain management. Supply Chain Management: An International Journal, 16(4), 231-245.

LARSEN, G. (2005) Horses for courses: relating innovation diffusion concepts to the stages of the diffusion process. Construction Management and Economics, 23, 787 792.

LATHAM, M. (1994) Constructing the Team, The final report of the Government / Industry review of procurement and contractual arrangements in the UK construction industry. London, HMSO.

LEIRINGER, R. \& CARDELLINO, P. (2008) Tales of the expected: investigating the rhetorical strategies of innovation champions. Construction Management and Economics, 26, 1043 - 1054. 
LONDON, K. A. \& KENLEY, R. (2001) An industrial organization economic supply chain approach for the construction industry: a review. Construction Management and Economics, 19, 777 - 788.

LOOSEMORE, M. (1999) A grounded theory of construction crisis management. Construction Management and Economics, 17, 9 - 19.

MACBETH, D. K. \& FERGUSON, N. (1994) Partnership Sourcing, an Integrated Supply Chain Approach. London, Financial Times / Pitman Publishing.

MANUJ, I., \& POHLEN, T. L. (2012). A reviewers guide to the grounded theory methodology in logistics and supply chain management research. International Journal of Physical Distribution \& Logistics Management, 42(8), 784-803.

MELLO, J. E. \& FLINT, D. J. (2009). A refined view of grounded theory annd its application to logistics research. Journal of Business Logistics, 30, 107 - 125.

MENG, X., SUN, M. \& MARTYN, J. (2011) Maturity Model for Supply Chain Relationships in Construction. Journal of Management in Engineering, April, 97 - 105.

MENTZER, J. T., DEWITT, W., KEEBLER, J. S., MIN, S., NIX, N. W., SMITH, C. D. \& ZACHARIA, Z. G. (2001) Defining Supply Chain Management. Journal of Business Logistics, 22, 1 - 25.

MEYER, J. W., \& ROWAN, B. (1977). Institutionalized organizations: Formal structure as myth and ceremony. American Journal of Sociology, 83(2), 340-363.

MIDDLETON, N., O'KEEFE, P. \& MAYO, S. (1993) Tears of the Crocodile: From Rio to Reality in the Developing World, London, Pluto Press.

MILLS, J., BONNER, A. \& FRANCIS, K. (2006) The Development of Constructivist Grounded Theory. International Journal of Qualitative Methods, 5, 25 - 35.

MORLEDGE, R., KNIGHT, A., GRADA, M. (2009) The concept and development of supply chain management in the UK construction industry in S. Pryke (Ed) Construction Supply chain Management: Concepts and case studies, WileyBlackwell, Chichester, 23 - 38

MURRAY, M., LANGFORD, D. (2003) Construction reports 1944-98, Blackwell, Oxford

NAM, C. H. \& TATUM, C. B. (1997) Leaders and champions for construction innovation. Construction Management and Economics, 15, 259 - 270.

O'BRIEN, W. J., FORMOSO, C. T., LONDON, K. A. \& VRIJHOEF, R. (2009) Introduction. IN O'BRIEN, W. J., FROMOSO, C. T., VRIJHOEF, R. \& KERRY, L. A. (Eds.) Construction Supply Chain Management Handbook. London, Taylor \& Francis Group. 
OMAR, A., DAVIS-SRAMEK, B., FUGATE, B. S., \& MENTZER, J. T. (2012). Exploring the complex social processes of organizational change: Supply chain orientation from a manager?s perspective. Journal of Business Logistics, 33(1), 4-19.

ORRÙ, M., BIGGART, N. W., HAMILTON, G.G. (1991). Organizational isomorphism in East Asia. The New Institutionalism in Organization Analysis, Powell, W. W., and DiMaggio, P.J. (ed), The University of Chicago Press, Chicago, 361-389.

O'SULLIVAN, B. (2011) Hard Numbers. Building Magazine. Building 2011.

OUCHI, W. G. (1980) Market, Bureaucracies, and Clans. Administrative Science Quarterly, 25, 129 - 141.

OUCHI, W. G. (1981) Theory Z How American business can meet the Japanese challenge, London, Addison-Wesley Publishing Company.

PRAJOGO, D., HUO, B., \& HAN, Z. (2012). The effects of different aspects of ISO 9000 implementation on key supply chain management practices and operational performance. Supply Chain Management: An International Journal, 17(3), 306-322.

PRYKE, S. (2009) Introduction. IN PRYKE, S. (Ed.) Construction Supply Chain Management Concepts and Case Studies. Oxford, Wiley-Blackwell.

RANDALL, W. S., \& MELLO, J. E. (2012). Grounded theory: An inductive method for supply chain research. International Journal of Physical Distribution \& Logistics Management, 42(8/9), 863-880.

REVE, T. \& LEVITT, R. (1984) Organization and governance in construction. International Journal of Project Management, 2, 17 - 25.

RICHEY, Jr. R.G., ROATH, A.S., WHIPPLE, J.M., FAWCETT, S.E. (2010) Exploring a governance theory of supply chain management: Barriers and facilitators to integration, Journal of Business Logistics, 31(1) 237 - 256

RICS (2010) Contracts in Use: A Survey of Building Contracts in Use during 2007. London, RICS.

RIMMER, B. (2009) Slough Estates in the 1990's - Client Driven SCM. IN PRYKE, S. (Ed.) Construction Supply Chain Management Concepts and Case Studies. Oxford, Wiley-Blackwell.

ROGERS, D. (2010) Top 150: How much further? Building Magazine. Building 2010.

ROGERS, D. 2010. Top 150: How much further? Building Magazine. Building 2010.

ROGERS, E. M. (1983) Diffusion of Innovations 3rd. Ed., New York, The Free Press. 
ROWLINSON, S. (1999) A definition of procurement systems. IN ROWLINSON, S. \& MCDERMOTT, P. (Eds.) Procurement Systems: a guide to best practice in construction. London, E \& FN Spon.

SAAD, M., JONES, M. \& JAMES, P. (2002) A review of the progress towards the adoption of supply chain management (SCM) relationships in construction. European Journal of Purchasing \& Supply Management, 8, 173 - 183.

SAHLIN, K. \& WEDLIN, L. (2008) Circulating Ideas: Imitation, Translation and Editing. IN GREENWOOD, D., OLIVER, C., SAHLIN, K. \& SUDDABY, R. (Eds.) The SAGE Handbook of Organizational Institutionalism. London, Sage.

SCOTT, R. W. (2008). Institutions and organizations ideas and interests London.

SHARMA, A. (1999) Central dilemmas of managing innovation in large firms. California Management Review, 41, 146 - 164.

SKITMORE, M. \& SMYTH, H. (2009) Marketing and Pricing Strategy. IN PRYKE, S. (Ed.) Construction Supply Chain Management Concepts and Case Studies. Oxford, Wiley-Blackwell.

STERN, P. N. (2010) On Solid Ground: Essential Properties for Growing Grounded Theory. IN BRYANT, A. \& CHARMAZ, K. (Eds.) The SAGE Handbook of Grounded Theory. London, SAGE Publications Ltd.

STUART, I. F. (1997) Supply-Chain Strategy: Organizational Influence Through Supplier Alliances. British Journal of Management, 8, 223 - 236.

SUDDABY, R. (2006) What grounded theory is not. Academy of Management Journal, 49, 633 - 642.

TAN, J. (2010) Grounded theory in practice: issues and discussion for new qualitative researchers, Journal of Documentation, Vol. 66 Iss: 1, pp.93 - 112

TENNANT, S. \& FERNIE, S. (2012) The commercial currency of construction framework agreements. Building Research \& Information, 40, 209 - 220.

THOMAS, R.W., CLIFFORD DEFEE, C., RANDALL, W.S., WILLIAMS, B. (2011) Assessing the managerial relevance of contemporary supply chain management research. International Journal of Physical Distribution \& Logistics Management, 41(7), pp.655- 667

TOMMELEIN, I. D., BALLARD, G. \& KAMINSKY, P. (2009) Supply Chain Management for Lean Project Delivery. IN O'BRIEN, W., J., FORMOSO, C., T., VRIJHOEF, R. \& LONDON, K. A. (Eds.) Construction Supply Chain Management Handbook. London, Taylor and Francis Group. 
Urquhart, C., Lehmann, H., \& Myers, M.D. (2010) Putting the 'theory' back into grounded theory: guidelines for grounded theory studies in information systems, Information Systems Journal, 20, 357-381

ÜSDIKEN, B., SŌZEN, Z., \& ENBIYAOǴLU, H. (1988). Strategies and boundaries: Subcontracting in construction. Strategic Management Journal, 9(6), 633-637.

VAN METER, K. (1990) Methodological and Design Issues: Techniques for Assessing Representatives of Snowballing Samples. In: LAMBERT, E. Y. (ed.) The Collection and Interpretation of Data from Hidden Populations. Washington D.C.: U.S. Government Printing Office.

VRIJHOEF, R. \& KOSKELA, L. (2000) The four roles of supply chain management in construction. European Journal of Purchasing \& Supply Management, 6, 169 - 178.

WALKER, D., \& MYRICK, F. (2006) Grounded Theory: An Exploration of Process and Procedure, Qualitative Health Research, 16: 547 -559.

WALSH, M. (2003) Teaching Qualitative Analysis Using QSR NVivo. The Qualitative Report, 8, 251 - 256.

WIENGARTEN, F., PAGELL, M., \& FYNES, B. (2012). ISO 14000 certification and investments in environmental supply chain management practices: Identifying differences in motivation and adoption levels between western european and north american companies. Journal of Cleaner Production, 1 - 11

WILHELM, M.M. (2011) Managing coopetition through horizontal supply chain relations: Linking dyadic and network levels of analysis. Journal of Operations Management, 29, 663 - 676

WILKINS, A. L. \& OUCHI, W. G. (1983) Efficient Cultures: Exploring the Relationship Between Culture and Organizational Performance. Administrative Science Quarterly, $28,468-481$.

WILLIAMSON, O. E. (1979). Transaction Costs Economics: The governance of contractual relations. Journal of Law and Economics, 22, 233-262.

WINCH, G. (1998) Zephyrs of creative destruction: understanding the management of innovation in construction. Building Research \& Information, 26, 268 - 279.

WOLSTENHOLME, A. (2009) Never waste a good crisis: A review of Progress since Rethinking Construction and Thoughts for Our Future. London, Constructing Excellence in the Built Environment.

WOOTEN, M. \& HOFFMAN, A. J. (2008) Organizational Fields: Past, Present and Future. IN GREENWOOD, R., OLIVER, C., SAHLIN, K. \& SUDDABY, R. (Eds.) The SAGE Handbook of Organisational Institutionalism. London, Sage. 